\title{
The Relation of 25-Hydroxyvitamin D Level with Metabolic Syndrome in Type 2 Diabetes Mellitus Patients
}

\author{
M.I. Diah Pramudianti ${ }^{1}$, Dian Ariningrum ${ }^{1}$, Medityas Winda Krissinta $^{2}$ \\ ${ }^{1}$ Department of Clinical Pathology, Faculty of Medicine, Sebelas Maret University/Dr. Moewardi Hospital, Surakarta, Indonesia. E-mail: \\ mi_diahp@yahoo.co.id \\ 2 Clinical Pathology Specialization Programme, Faculty of Medicine, Sebelas Maret University/Dr. Moewardi Hospital, Surakarta, Indonesia. \\ E-mail:medityas@gmail.com
}

\section{ABSTRACT}

Type 2 Diabetes Mellitus (DM) is a metabolic disorder characterized by hyperglycemia. Metabolic Syndrome (MS) is a complex metabolic disorder like hyperglycemia, obesity, dyslipidemia, and hypertension. Vitamin D controls genes associated with the regulation of insulin and renin production. The aim of this study was to analyze the relation between total levels of 25-hydroxyvitamin D [25(OH)D] and the incidence of MS in type 2 DM patients. This was an observational study with a cross-sectional design conducted from October to November 2018 in Dr. Moewardi Hospital Surakarta on 84 people with type $2 \mathrm{DM}$. All subjects were 34-75 years old. The research data were analyzed with a $2 \times 2$ test table to determine the Prevalence Ratio (PR) of each study variable, then multivariate analysis with logistic regression was continued. The mean total level of $25(\mathrm{OH}) \mathrm{D}$ was $18.01 \pm 6.10 \mathrm{ng} / \mathrm{dL}$. Bivariate and continued with multivariate PR analysis showed poor glycemic control with the incidence of MS (PR: 11.154; 95\% Cl: 3.933-31.631; $\mathrm{p}=0.001)$; female sex (PR : 1.788; 95\% Cl: 0.750-4.261; $\mathrm{p}=0.188$ ); age < 50 year (PR: 1.644; 95\% Cl: 0.614-4.404; $\mathrm{p}=0.321)$; and total 25(OH)D deficiency (PR: $1.250 ; 95 \%$ $\mathrm{Cl}: 0.317-2.022 ; \mathrm{p}=0.637)$. Total $25(\mathrm{OH}) \mathrm{D}$ level was not associated with the incidence of MS in the type $2 \mathrm{DM}$ patients. Further study was needed using healthy group control to explain the role of vitamin D in type 2 DM.

Keywords: Type 2 DM, metabolic syndrome, 25(OH)D

\section{INTRODUCTION}

According to the Indonesian Endocrinology Association (Perkeni), type 2 Diabetes Mellitus (DM) is a metabolic disease characterized by hyperglycemia that occurs due to damage to insulin action and/or abnormal insulin secretion. According to the International Diabetes Federation (IDF), Indonesia has the $7^{\text {th }}$ most significant number of people with diabetes in the world after China, India, the United States, Brazil, Rusia, and Mexico. The World Health Organization (WHO) has predicted an increase in the number of people with DM in Indonesia from 8.4 million in 2000 to around 21.3 million in 2030., ${ }^{1,2}$

Metabolic Syndrome (MS) is a metabolic complex disorder with several cardiovascular risk factors. The prevalence of the MS population has increased from year to year, which reaches the prevalence of $20-25 \%$ of the world's adult population. The more components of MS, the higher the cardiovascular mortality rate. So that the risks of death are doubled, and heart attack or stroke is tripled. The clinical criteria for MS used by clinicians are by WHO 1999,
The USA Cholesterol Education Panel Adult Treatment Panel III (NCEP-ATP III) 2001, and IDF 2005. The three main guidelines have different but benchmark including central obesity, dyslipidemia, hyperglycemia, and hypertension. ${ }^{3.4}$

The Asian modification NCEP-ATP III criteria must have at least three of the five MS benchmarks including Fasting Blood Glucose (FBG) $\geq 100 \mathrm{mg} / \mathrm{dL}$ or receiving anti-hyperglycemia treatment, blood pressure $\geq 130 / 85 \mathrm{mmHg}$ or receiving anti hypertensive treatment, triglycerides (TG ) $\geq 150$ $\mathrm{mg} / \mathrm{dL}$, high density lipoprotein cholesterol (HDL-C) $<40 \mathrm{mg} / \mathrm{dL}$ for males and $<50 \mathrm{mg} / \mathrm{dL}$ for females or receiving treatment for dyslipidemia and central obesity (male waist circumference $\geq 90 \mathrm{~cm}$, female $\geq$ $80 \mathrm{~cm})^{3,4}$

Vitamin D (calciferol) is a fat-soluble pro steroid hormone (secosteroid). Physiologically relevant vitamin D is D2 (ergocalciferol) and D3 (cholecalciferol). The forms of D3 and D2 differ only in their chain structure, but these differences do not affect metabolism, and both forms function as prohormones. Inactive vitamin $\mathrm{D}$ metabolite is 25 -hydroxyvitamin $\mathrm{D}[25(\mathrm{OH}) \mathrm{D}]$ which is also called 
calcidiol or calcifediol, while the active metabolite of vitamin $\mathrm{D}$ is 1.25 -dihydroxy vitamin $\mathrm{D}$ [1.25(OH)2D] known as calcitriol or 1.25-dihydroxy cholecalciferol. ${ }^{5}$

The best indicator of vitamin $D$ status is serum total 25(OH)D level because 25(OH)D has a half-life in a long circulation period of 3-4 weeks so that a decrease in $25(\mathrm{OH}) \mathrm{D}$ level reflects vitamin $\mathrm{D}$ status in the body. The serum level of $1.25(\mathrm{OH}) 2 \mathrm{D}$ is not recommended for determining vitamin $\mathrm{D}$ status because the half-life in circulation is short at 4-6 hours, and blood circulating level is very low, which is 1,000 times lower than the total $25(\mathrm{OH}) \mathrm{D}$ level. The cut-off value of vitamin $D$ deficiency is a total serum level of $25(\mathrm{OH}) \mathrm{D}<20 \mathrm{ng} / \mathrm{mL}^{6.7}$

Vitamin $D$ has a pleiotropic cardiovascular effect by activating vascular endothelial cells, regulating the Renin-Angiotensin-Aldosterone System (RAAS), adipose tissue, energy expenditure, and pancreatic cell activity. It plays a role in pancreatic function because $1.25(\mathrm{OH}) 2 \mathrm{D}$ receptors and $1 \alpha$ expression are identified as hydroxylase in pancreatic beta cells, which supports the possible role of vitamin $D$ in type $2 \mathrm{DM}$ pathogenesis. The effect of vitamin $\mathrm{D}$ on insulin synthesis and secretion is evidenced by the response elements of vitamin $D$ (REVD) in human insulin gene promoters and activation of human insulin gene transcription caused by $1.25(\mathrm{OH}) 2 \mathrm{D}$. Peroxisome Proliferator-Activated Receptor (PPAR) is the first gene identified associated with type $2 \mathrm{DM}^{5,8}$

Vitamin $D$ deficiency may result from the lack of UV exposure and the food containing vitamin D. Vitamin $D$ deficiency may cause vascular dysfunction, left ventricular hypertrophy, DM, hypertension, and dyslipidemia. ${ }^{6,7}$

Research in various countries regarding the relation between total 25(OH)D level and the incidence of MS in type 2 DM patients revealed different results as there are many clinical criteria. In this study, the MS criteria were based on the NCEP ATP III 2001 as were easier to examine and apply. This research aimed to analyze the relation of total 25(OH)D level with the incidence of MS in type $2 \mathrm{DM}$ patients.

\section{METHODS}

This study was an observational study with a cross-sectional approach. This study compared two groups consisting of DM type 2 with and without MS. Diabetes mellitus patients diagnosed by clinicians in the Internal Medicine Outpatient Clinic of the Endocrinology Sub-Department who underwent laboratory examinations at the Clinical Pathology Laboratory of the Dr. Moewardi Hospital (RSDM)
Surakarta from October to November 2018. A total of 84 subjects met our inclusion criteria.

Patients with type $2 \mathrm{DM}$, males, and females, aged over 25 years old and agreed to participate in the study by signing an informed consent were included in our study. Subjects with the history or suffering from liver and kidney diseases (obtained from the history or medical record data), bone abnormalities (rickettsia, bone deformities, osteomalacia), $\mathrm{Hb}$ variant abnormalities/hemoglobinopathy (thalassemia), anemia, pregnancy, medications that affected vitamin D level (Carbamazepine, Phenytoin) were excluded from the study.

Laboratory tests were preceded by tests of accuracy and analytical accuracy so that the quality of the results of the examination could be reliable. The data were tested for data normality by using the Kolmogorov Smirnov test, presented in mean \pm Standard Deviation (SD) for normal distribution and median (minimum-maximum) for abnormal distribution. The bivariate analysis used a $2 \times 2$ Chi-Square test to obtain for PR and 95\% Confidence Intervals (CI). Multivariate analysis was used to analyze the effect of other variables on the incidence of MS. Statistical analysis was processed with a computer program, $\mathrm{p}<0.05$ was considered as significant. This research had also been submitted to the ethics committee of the Health Research Ethics Commission of Moewardi Hospital/Medical Faculty of Sebelas Maret University with number 739/X/HREC/2018.

\section{RESULTS AND DISCUSSION}

The results of within-day and between-day accuracy tests of $\mathrm{HbAlc}, \mathrm{TG}, \mathrm{HDL}-\mathrm{C}$, low-density lipoprotein cholesterol (LDL-C), FBG, and a total of 25(OH)D were exellent and showed the accuracy that persisted over time. The baseline characteristics of the study subjects were presented in Table 1 consisting, 42 (50\%) type 2 DM subjects with MS and as a control 42 (50\%) type 2 DM subjects without MS.

The baseline characteristic data of the study subjects showed lower HDL-C level and higher BMI, WC, SBP, FBG, and TG levels in the type 2 DM group with MS than those in the non-MS group (Table 2). These results were consistent with the characteristics of the MS by NCEP-ATP III criteria i.e., central obesity, hypertension, elevated TG, HDL-C reduction, and an elevated FBG.

The risk factors for MS varied in each race (or population). This study used variables of gender, age, glycemic control, and total 25(OH)D level (Table 3). The results of the comparison of the study variables were explained in boxplot (Figure 1). This 
Table 1. Baseline characteristics of the study subjects

\begin{tabular}{|c|c|c|}
\hline Variable & Mean \pm SD & Median (min-max) \\
\hline Duration of DM (year) $^{a}$ & & $8.00(6.00-10.00)$ \\
\hline BMI $\left(\mathrm{kg} / \mathrm{m}^{2}\right)^{\mathrm{b}}$ & $26.15 \pm 4.01$ & \\
\hline Body weight $(\mathrm{kg})^{a}$ & & $64.00(58.25-73.75)$ \\
\hline Body height $(\mathrm{cm})^{\mathrm{b}}$ & $158.86 \pm 6.43$ & \\
\hline$W C(\mathrm{~cm})^{\mathrm{b}}$ & & $84.00(79,00-89.75)$ \\
\hline $\mathrm{SBP}(\mathrm{mmHg})^{a}$ & & $120.00(110.00-140.00)$ \\
\hline $\mathrm{DBP}(\mathrm{mmHg})^{a}$ & & $80.00(70.00-80.75)$ \\
\hline $\mathrm{FBG}(\mathrm{mg} / \mathrm{dL})^{\mathrm{a}}$ & & $159.00(130.50-196.75)$ \\
\hline $\mathrm{TG}(\mathrm{mg} / \mathrm{dL})^{\mathrm{a}}$ & & $139.00(112.25-175.25)$ \\
\hline $\mathrm{HDL}-\mathrm{C}(\mathrm{mg} / \mathrm{dL})^{\mathrm{b}}$ & $48.93 \pm 11.89$ & \\
\hline $\mathrm{LDL}-\mathrm{C}(\mathrm{mg} / \mathrm{dL})^{\mathrm{b}}$ & $122.4 \pm 30.91$ & \\
\hline
\end{tabular}

a: abnormal data distribution [median (Min-Max)]; b: normal data distribution (mean \pm SD)

Description: SD: Standard Deviation; DM: Diabetes Mellitus; MS: Metabolic Syndrome; BMI: Body Mass Index; WC: Waist Circumference; SBP: Systolic Blood Pressure; DBP: Diastolic Blood Pressure; TG: Triglycerides; HDL: Cholesterol High-Density Lipoprotein; LDL: Cholesterol Low-Density Lipoprotein; kg: Kilograms; mg: Milligram; cm: Centimeter; $\mathrm{dL}$ : Deciliter; $\mathrm{mmHg}$ : Millimeter of mercury

Table 2. Comparison of baseline characteristics by the incidence of MS

\begin{tabular}{|c|c|c|c|}
\hline Variable & $\begin{array}{l}\text { DM Type } 2 \text { with MS } \\
(n=42)\end{array}$ & $\begin{array}{l}\text { DM Type } 2 \text { without MS } \\
(n=42)\end{array}$ & $\mathbf{p}$ \\
\hline Duration of DM (year) $^{a}$ & $8.00(6.00-11.00)$ & $8.00(6.00-10.00)$ & 0.465 \\
\hline BMI $\left(\mathrm{kg} / \mathrm{m}^{2}\right)^{\mathrm{b}}$ & $27.10 \pm 4.35$ & $25.21 \pm 3.43$ & $0.029 *$ \\
\hline Body weight $(\mathrm{kg})^{b}$ & $68.17 \pm 12.55$ & $63.90 \pm 8.69$ & 0.075 \\
\hline Body height $(\mathrm{cm})^{\mathrm{b}}$ & $158.38 \pm 6.59$ & $159.33 \pm 6.32$ & 0.501 \\
\hline$W C(\mathrm{~cm})^{b}$ & $88.46 \pm 10.55$ & $82.40 \pm 7.58$ & $0.003^{*}$ \\
\hline $\mathrm{SBP}(\mathrm{mmHg})^{a}$ & $133.00(113.75-140.25)$ & $120.00(110.00-137.25)$ & $0.024^{*}$ \\
\hline $\mathrm{DBP}(\mathrm{mmHg})^{a}$ & $80.00(70.00-85.50)$ & $80.00(70.00-80.00)$ & 0.555 \\
\hline FBG $(\mathrm{mg} / \mathrm{dL})^{\mathrm{a}}$ & $170.50(141.75-227.25)$ & $142.50(127.50-179.00)$ & $0.011^{*}$ \\
\hline $\mathrm{TG}(\mathrm{mg} / \mathrm{dL})^{\mathrm{a}}$ & $174.50(124.75-256.25)$ & $124.00(104.75-139.75)$ & $0.001^{*}$ \\
\hline $\mathrm{HDL}-\mathrm{C}(\mathrm{mg} / \mathrm{dL})^{\mathrm{b}}$ & $45.14 \pm 12.46$ & $52.71 \pm 10.08$ & $0.003^{*}$ \\
\hline $\mathrm{LDL}-\mathrm{C}(\mathrm{mg} / \mathrm{dL})^{\mathrm{b}}$ & $126.00 \pm 33.94$ & $118.07 \pm 27.39$ & 0.242 \\
\hline
\end{tabular}

a: abnormal data distribution [median (Min-Max)], different test with Mann-Whitney

b: normal data distribution (mean \pm SD), different test with independent T-test

${ }^{*} \mathrm{p}<0.05$ is significant

Description: SD: Standard Deviation; DM: Diabetes Melitus; MS: Metabolic Syndrome; BMI: Body Mass Index; WC: Waist Circumference; SBP: Systolic Blood Pressure; DBP: Diastolic Blood Pressure; TG: Triglycerides; HDL: Cholesterol High-Density Lipoprotein; LDL: Cholesterol Low-Density Lipoprotein; kg: Kilograms; mg: Milligram; cm: Mentimeter; $\mathrm{dL}$ : Deciliter; mmHg: Millimeter of mercury

study obtained 22 (52.4\%) females and 20 (47\%) males in type 2 DM with MS group.In type $2 \mathrm{DM}$ without MS, there were 16 (38.1\%) females and 26 (61.9\%) males. A cross-sectional study in Iran by Eftekhari et al. showed that the prevalences LP, FBG, $\mathrm{TG}$, and hypertension were significantly higher in the group of females than males $(p=0.001 ; p-0.031$; $p=0.017 ; p=0.015)^{9}$

Central obesity is caused by a lack of physical activity as well as excessive nutrition. There are more than 70 different gene loci that contribute to the adipose phenotype. Mutations in the PPAR gene affect obesity differently in females and males. Two polymorphisms in the PPAR gamma-2 gene are associated with severe overweight in females only. This fact suggests that inherited factors may play different roles in females and males. The pattern of lipid accumulation differs between females and males. Lipid accumulation in females occurs peripheral adipocytes with gluteal fat accumulation, whereas males are more susceptible to central obesity. $^{10,11}$

There was no significant difference in age between type 2 DM with MS and without MS 
Table 3. Comparison of the subject variables of research

\begin{tabular}{|c|c|c|c|c|}
\hline Variable & $\begin{array}{c}\text { Total } \\
(n=84)\end{array}$ & $\begin{array}{c}\text { Type } 2 \text { DM with MS } \\
(n=42)\end{array}$ & $\begin{array}{l}\text { Type } 2 \text { DM without MS } \\
(\mathrm{n}=42)\end{array}$ & $\mathbf{p}$ \\
\hline Gender & & & & - \\
\hline Males & $46(54.8 \%)$ & $20(47.6 \%)$ & 26 (61.9\%) & \\
\hline Females & $38(45.2 \%)$ & $22(52.4 \%)$ & $16(38.1 \%)$ & \\
\hline Age $\left(\right.$ year) ${ }^{a}$ & $59(48.25-64.75)$ & $58,5(45.75-63.0)$ & $61(51.5-65.25)$ & 0.232 \\
\hline$\geq 50$ year & $62(73.8 \%)$ & $29(69.0 \%)$ & $33(78.6 \%)$ & \\
\hline$<50$ year & $22(26.2 \%)$ & $13(31.0 \%)$ & $9(21.4 \%)$ & \\
\hline Glycemic control $^{b}$ & $7.77 \pm 1.68$ & $8.65 \pm 1.69$ & $6.88 \pm 1.11$ & $0.001^{*}$ \\
\hline Good & 36 (42.9\%) & 7 (16.7\%) & 29 (69.0\%) & \\
\hline Poor & $48(57.1 \%)$ & 35 (83.3\%) & $13(31.0 \%)$ & \\
\hline Total 25(OH)D (ng/dL) ${ }^{b}$ & $18.01 \pm 6.10$ & $17.35 \pm 6.48$ & $18.67 \pm 5.70$ & 0.326 \\
\hline Normal & 26 (31.0\%) & $12(28.6 \%)$ & $14(33.3 \%)$ & \\
\hline Deficiency & $58(69.0 \%)$ & $30(71.4 \%)$ & $28(66.7 \%)$ & \\
\hline
\end{tabular}

a: abnormal data distribution; b: normal data distribution, ${ }^{*} \mathrm{p}<0.05$ significant.

Description: DM: Diabetes Melitus; MS: Metabolic Syndrome; ng: Nanogram; dL: Deciliter; Good glycemic control: HbA1c

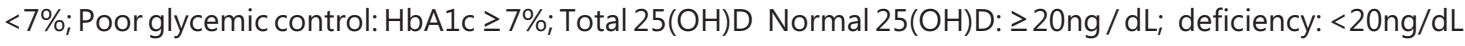

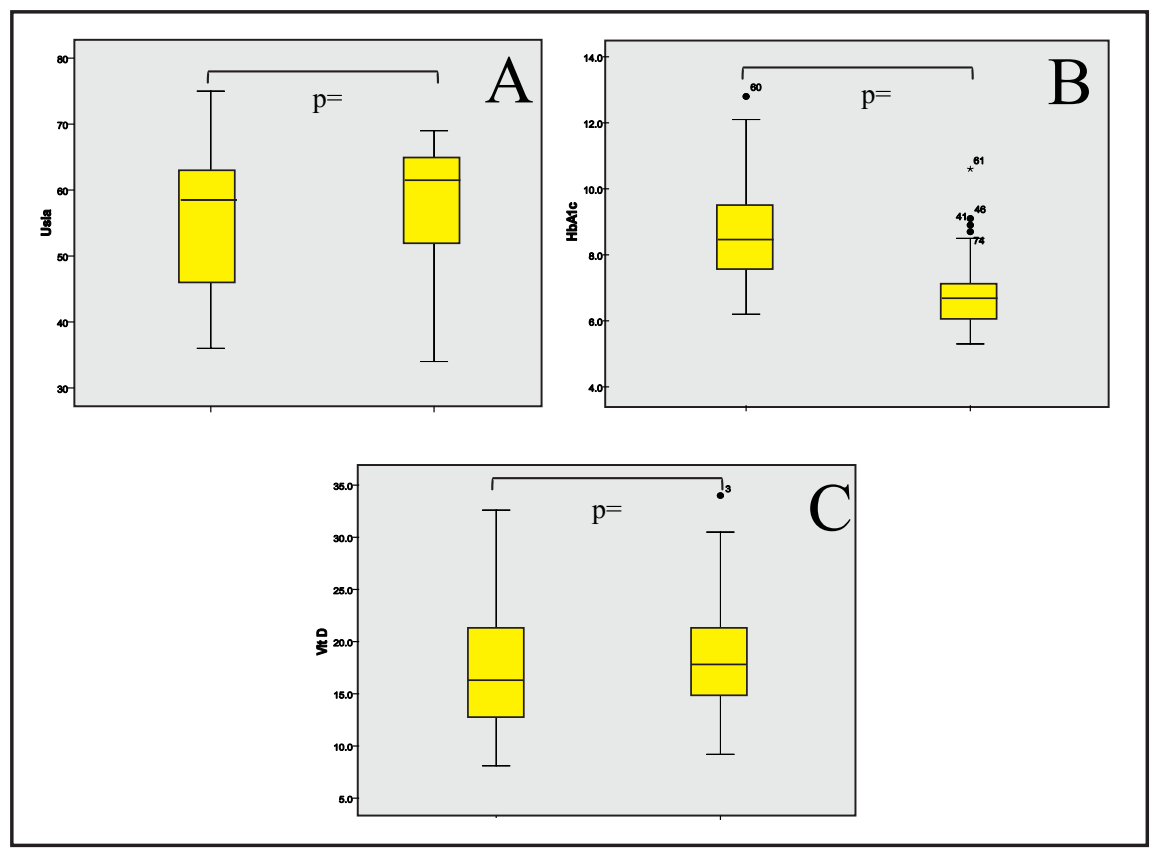

Figure 1. Box plot comparison of research variables with the incidence of $M S(A)$ age; (B) glycemic control; (C) total 25(OH)D level

$(p=0.232)$. This finding was different from Prasad et al. study which reported that older age was more common in MS than without MS ( $p<0.001){ }^{12}$ Ogbera's study showed a significant increase in age with an increased risk of MS $(p=0.001){ }^{13}$ A study by Kraja et al. reported that the prevalence of MS increased by 2 to 3 times at the age over 50 years old. $^{14}$

This research on the $\mathrm{HbAlc}$ level showed a statistically significant difference between the DM type 2 group and MS compared without MS
(Table 4). HbA1c level in type 2 DM subjects with MS was higher than type $2 \mathrm{DM}$ without MS, which was $8.65 \pm 1.69$ vs. $6.88 \pm 1.11$ ( $p=0.001)$. This study was in accordance with the research of Al et al., showing that there was a statistically significant difference between the MS groups compared to without MS $(p=0.027){ }^{15}$ This result was different from Prasad et al., who showed that $\mathrm{HbA} 1 \mathrm{c}$ level did not show a statistically significant difference between the type 2 DM and MS compared without MS $(p=0.08) .{ }^{12}$ These results proved that $\mathrm{HbA} 1 \mathrm{c}$ was associated with type 2 
DM with MS compared to without MS.

In this study, total of $25(\mathrm{OH}) \mathrm{D}$ levels was not statistically significant different between type $2 \mathrm{DM}$ with MS and without MS ( $p=0.326)$. This finding was similar to that of Al et al., which also revealed that total $25(\mathrm{OH}) \mathrm{D}$ level did not show a statistically significant difference between the two groups $(p=0.061) .{ }^{15}$ However, these findings differ from those of Gradillas-Garcia et al., showing a statistically significant difference between the 25(OH)D deficiency group compared with $25(\mathrm{OH}) \mathrm{D}$ deficiency. ${ }^{16}$ Studies by Fondjo et al. showed a significant difference of total $25(\mathrm{OH}) \mathrm{D}$ level between type $2 \mathrm{DM}$ and non-type $2 \mathrm{DM}{ }^{17}$

Tenenbaum et al. reported that patients with type 2 DM usually experienced excessive adipogenesis (obesity) and the modulation of nuclear Peroxisome Proliferator-Activated Receptor (PPAR). Peroxisome proliferator-activated receptor is a transcription factor activated by ligands, include steroid receptors and thyroid hormone; PPAR regulates the expression of many genes and affects glycemic control, lipids metabolism, and inflammation. ${ }^{18}$ Bland et al. convey the effect of vitamin $D$ on the synthesis and secretion of insulin, as evidenced by the presence of REVD in the promoter of the human insulin gene. ${ }^{8}$

Bivariate analysis in this study revealed that sex was not related to the incidence of MS in type $2 \mathrm{DM}$ patients (PR: $1.788 ; 95 \% \mathrm{Cl}: 0.750-4.261 ; \mathrm{p}=0.188$ ). This finding was different from the study by Prasad et al. in India, showing that females were statistically significant for an increase in MS risk (PR: 2.09; 95\% Cl: $1.65-2.65 ; p=0.000){ }^{12}$

Age was also not related to the incidence of MS in type 2 DM patients (PR:1.644; 95\%
Cl: $0.614-4.404 ; p=0.321)$. In contrast to the study by Gradillas-Garcia et al. who reported that subjects aged $\geq 53$ years (PR: 4.32; 95\% CI: 2.33-8.02; $\mathrm{p}<0.001$ ) in subjects with MS. ${ }^{16}$ Prasad et al. study reported that ages 45-64 (PR: 4.52; 95CI: 3.47-5.90; $p=0.000$ ) and age $\geq 64$ (PR: 4.51; 95CI: 3.05-6.68; $\mathrm{p}=0.000$ ) contributed significantly to an increase of MS risk. ${ }^{12}$

In this study, glycemic was associated with the incidence of MS in patients with type 2 DM (PR: 11.154; 95\% CI: 3.933 to $31.631 ; p=0.001$ ). Patients with poorly controlled glycemia had a risk of MS 11.154 times greater than well-controlled one. Athanassiou et al. stated that the level of vitamin D was associated with glycemic control in type $2 \mathrm{DM}^{19}$ This statement was different from the study result of Worawongprapa in patients either with or without MS. ${ }^{20}$

Total 25(OH)D level was not related to the incidence of MS (PR: 1.250 (95\% Cl: 0.317-2.022; $\mathrm{p}=0.637$ ). Gradillas-Garcia et al. study stated different result in the adult population in Madrid, showing total $25(\mathrm{OH}) \mathrm{D}<20 \mathrm{ng} / \mathrm{mL}$ (PR:2.02; $95 \% \mathrm{CI}$ : 1.11-3.70; $p=0.021){ }^{16}$

Multivariate analysis of backward method logistic regression was conducted to find out more about the possible relationship between $25(\mathrm{OH}) \mathrm{D}$ total level and other variables (gender, age, glycemic control) that affected the incidence of MS in type 2 DM patients (Table 5). Variable glycemic control showed a relationship with the incidence of MS in type 2 DM patients a (PR: 1.154: 95\% Cl: $3.933-31,631 ; p=0.001)$. A multivariate analysis in India by Prasad et al. showed that predictor variables for the incidence of MS were females (PR: 3.104; 95\% Cl: 2.29-4.19; $p=0.000)$, age 45-64

Table 4. Bivariate analysis of $2 \times 2$ test tables between total $25(\mathrm{OH}) \mathrm{D}$ level and other variables that might affect the incidence of MS in type 2 DM patients

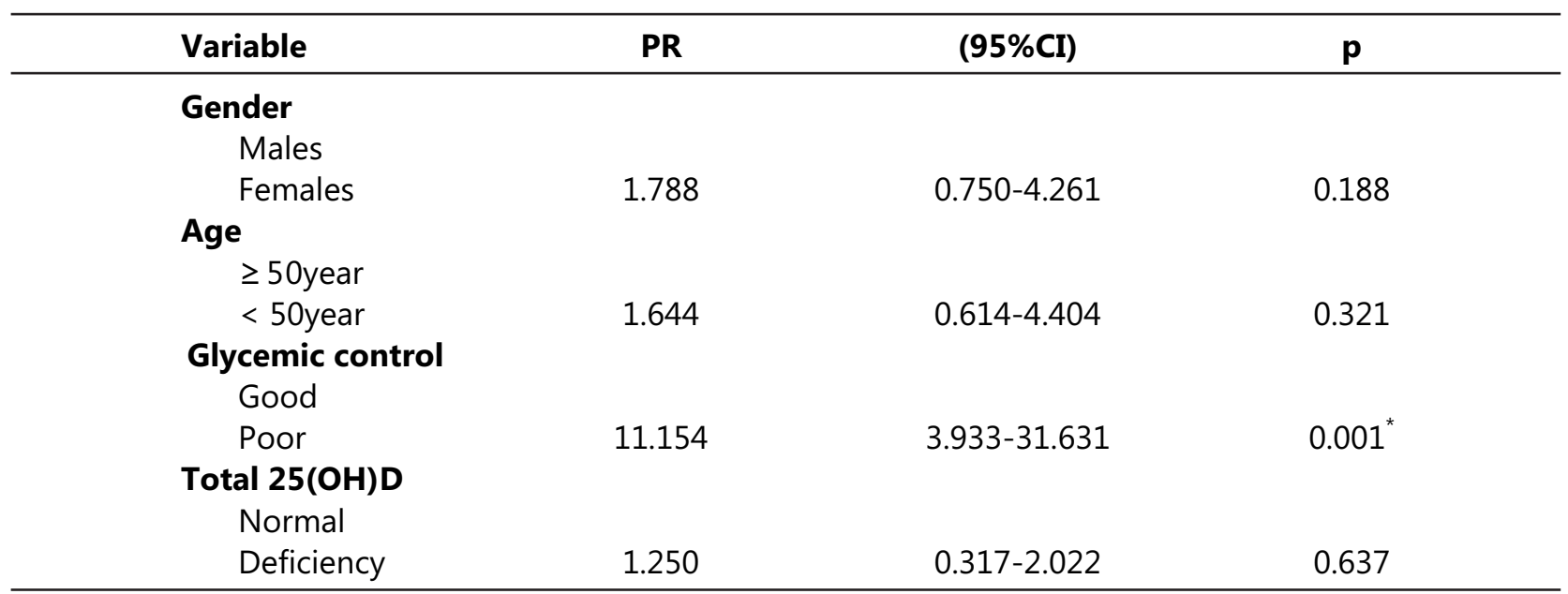

Description: DM : Diabetes Melitus; MS : Metabolic Syndrome; $\mathrm{p}=$ Probabilitas; PR : Prevalance Ratio, CI: Confidence Interval; 25(OH)D: 25 hydroxyvitamin $\mathrm{D} ;{ }^{*} \mathrm{p}<0.05$ significant 
Table 5. Results of multivariate logistic regression analysis of total $25(\mathrm{OH}) \mathrm{D}$ level and other variables affecting the incidence of MS in type 2 DM patients

\begin{tabular}{lccc}
\hline Variable & PR & $\mathbf{9 5 \% C I}$ & $\mathbf{P}$ \\
\hline Model 1 & 1.798 & $0.573-5.637$ & 0.315 \\
$\quad$ Females & 1.589 & $0.487-5.187$ & 0.443 \\
$\quad$ <50 years old & 11.991 & $3.984-36.095$ & $0.001^{*}$ \\
$\quad$ Poor glycemic control & 0.506 & $0.140-1.827$ & 0.299 \\
$\quad$ Total 25(OH)D & & & \\
Model 2 & 1.805 & $0.578-5.639$ & 0.310 \\
$\quad$ Females & 12.055 & $4.019-36.155$ & $0.001^{*}$ \\
$\quad$ Poor glycemic control & 0.526 & $0.146-1.893$ & 0.325 \\
$\quad$ Total 25(OH)D & & & \\
Model 3 & 1.400 & $0.506-3.872$ & 0.517 \\
$\quad$ Females & 10.724 & $3.762-30.571$ & $0.001^{*}$ \\
$\quad$ Poor glycemic control & & & \\
Model 4 & 11.154 & $3.933-31.631$ & $0.001^{*}$ \\
$\quad$ Poor glycemic control &
\end{tabular}

${ }^{*} \mathrm{p}<0.05$ significant; CI: Confidence Interval, PR: Prevalance Ratio

years (PR: $4.666 ; 95 \% \mathrm{Cl}: 3.42-6.34 ; \mathrm{p}=0.000)$ and $\geq 64$ years (PR: $5.058 ; 95 \% \mathrm{Cl}: 3.78-6.75 ; \mathrm{p}=0.000$ ). ${ }^{12}$

The results of this study, only glycemic control was significantly associated with the occurrence of MS in type 2 DM patients so that poor glycemic control was an independent predictor variable for the incidence of MS in type $2 \mathrm{DM}$ patients, in contrast gender, age and total $25(\mathrm{OH}) \mathrm{D}$ level was not associated with the incidence of MS in type 2 DM patients. It was concluded that the total 25(OH)D level was not associated with the incidence of MS in the type $2 \mathrm{DM}$ patient group. This was because perhaps vitamin $D$ was not the main pro-inflammatory factor that spurred the onset of MS.

The limitations of this current study were that our subjects aged between 34 and 74 years. Elderly, post-menopausal females are one of the risk factors that are causing vitamin $D$ deficiency. Indonesia is a tropical country but the average total $25(\mathrm{OH}) \mathrm{D}$ level of 84 subjects in this study was $18.01 \pm 6.10 \mathrm{ng} / \mathrm{dL}$. This finding was probably due to the use of covered clothing (headscarves), the use of sunblock protection creams, less outdoor activity, so that the skin was less exposed to sunlight. A low intake of foods containing vitamin $D$ may also have contributed to a greater prevalence of deficiency vitamin D.

\section{CONCLUSION AND SUGGESTION}

In conclusion, the total level of $25(\mathrm{OH}) \mathrm{D}$ was not associated with the incidence of MS patients with type $2 \mathrm{DM}$. It is suggested a follow-up case-control study, including age stratification in females based on menopausal status, to define the role of vitamin $D$ in the development of type 2 DM better, and clarify the relations between level of 25(OH)D and other variables with the occurrence of MS in type $2 \mathrm{DM}$ patients.

\section{REFERENCES}

1. PERKENI. Konsensus pengelolaan dan pencegahan diabetes melitus tipe 2 di Indonesia 2015. In; 2015: Pengurus Besar Perkumpulan Endokrinologi Indonesia (PB PERKENI). 2015; 1-14.

2. International Diabetes Federation. IDF diabetes atlas. sixth Ed., 2013 [cited August 15, 2018]. Available at: www.idf.org/diabetesatlas.

3. Milici N. A Short history of the metabolic syndrome definitions. Proc. Rom. Acad. 2010; 13-20.

4. International Diabetes Federation. The IDF consensus worldwide definition of the metabolic syndrome.2006 [cited at Juni 15, 2018]. Available at: https://www.idf. org/component/attachments/attachments.HTML?id =705\&task=download.

5. Bikle DD. Vitamin D metabolism, mechanism of action, and clinical application. Chemistry \& Biology, 2014; 21:319-329.

6. Cândido FG, Bressan J. Vitamin D: Link between osteoporosis, obesity, and diabetes?. Int. J. Mol. Sci, 2014; 15: 6569-6591.

7. Strange RC, Shipman KE, Ramachandran S. Metabolic syndrome: A review of the role of vitamin $D$ in mediating susceptibility and outcome. World J Diabetes, 2015; 6(7): 896-911.

8. Bland R, Markovic D, Hills CE, Hughes SV, Chan SL, et al. Expression of 25-hydroxyvitamin D3-1 - alpha-hydroxylase in pancreatic islets. Journal of Steroid Biochemistry \& Molecular Biology, 2004; 89-90: 121-125.

9. Eftekhari MH, Sohrab Z, Parsa N, Nezhad MJZ. Role of gender in the prevalence of metabolic syndrome and 
its related risk factors in shiraz healthy heart center population. Int Cardiovasc Res J, 2015; 9(4): 231-237.

10. Valve $R$, Sivenius $R$, Miettinen $R$, Pihlajamaki J, Rissanen $A$, et al. Two polymorphisms in the peroxisome proliferator-activated receptor-g gene are associated with severe overweight among obese women. The Journal of Clinical Endocrinology \& Metabolism, 1999; 84(10): 3708-3712.

11. Williams CM. Lipid metabolism in women. Proceedings of the Nutrition Society. 2004; 63: 153-160.

12. Prasad K, Dash AK, Das BC. Prevalence and risk factors for metabolic syndrome in Asian Indians: A community study from urban Eastern India. J Cardiovasc Dis Res, 2012; 3(3): 204-211.

13. Ogbera AO. Prevalence and gender distribution of the metabolic syndrome. Diabetology and Metabolic Syndrome, 2010; 2(1): 1-5.

14. Kraja AT, Borecki IB, North $K$, Tang W, Myers RH, Hopkins $\mathrm{PN}$, et al. Longitudinal and age trends of metabolic syndrome and its risk factors: The family heart study. Nutrition \& Metabolism, 2006; 3(41): 1-9.

15. Al LİR, Sönmezer MÇ, Çiçek AG, Keskin M, Efe FK, Çimen IM. Evaluation of the relationship between vitamin $D$ levels and metabolic syndrome components. Biomed Res, 2017; 28(20): 8821-8826.

16. Gradillas-Garcíaa A, Álvarez J, Rubiob JA, de Abajo FJ. Relationship between vitamin $D$ deficiency and metabolic syndrome in adult population of the Community of Madrid. Endocrinol Nutr, 2015; 62(4): 180-187.

17. Fondjo LA, Owiredu WKBA, Sakyi SA, Laing EF, Adotey-Kwofie MA, et al. Vitamin D status and its association with insulin resistance among type 2 diabetics: A case-control study in Ghana. 2017 [cited at September 10, 2018] Available at: https://doi.org/10.1371/journal.pone.0175388.

18. Tenenbaum A, Fisman EZ, Motro M. Metabolic syndrome and type 2 diabetes mellitus: Focus on peroxisome proliferator-activated receptors (PPAR). Cardiovascular Diabetology, 2003; 2: 1-7.

19. Athanassiou IK, Athanassiou P, Gkountouvas A, Kaldrymides $P$. Vitamin $D$ and glycemic control in diabetes mellitus type 2. Ther Adv Endocrinol Metab, 2013; 4(4): 122-128.

20. Worawongprapa O. Glycemic control in diabetes with metabolic syndrome in community hospital. J Med Assoc Thai, 2008; 91(5): 641-647. 